Prepared in cooperation with the West Virginia Department of Agriculture

\title{
Interlaboratory Comparison of Results for Three Microbial Source Tracking Quantitative Polymerase Chain Reaction (qPCR) Assays from Fecal-Source and Environmental Samples
}

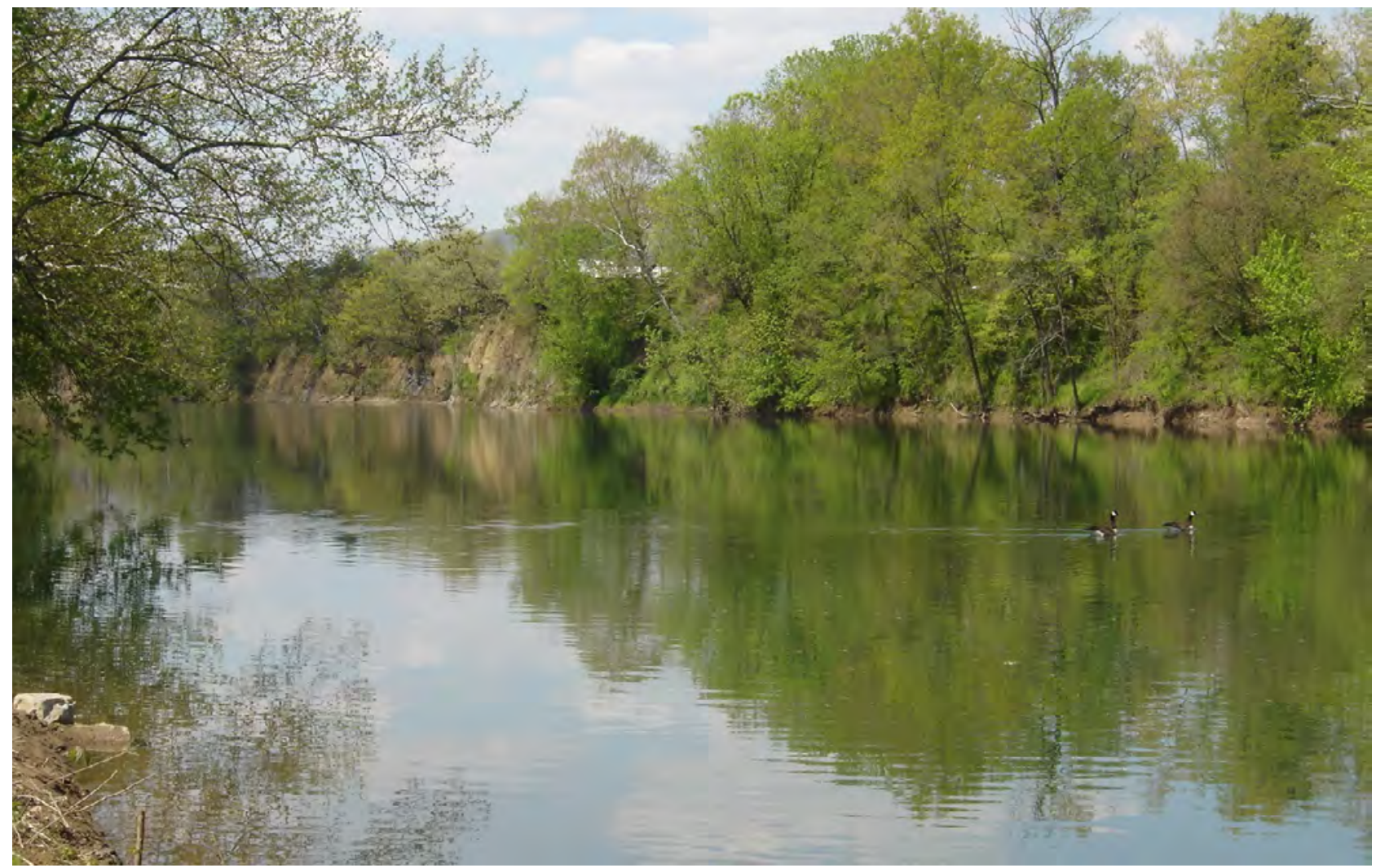

Scientific Investigations Report 2012-5087 
Cover photo courtesy of West Virginia Department of Agriculture. 


\section{Interlaboratory Comparison of Results for Three Microbial Source Tracking Quantitative Polymerase Chain Reaction (qPCR) Assays from Fecal-Source and Environmental Samples}

By Erin A. Stelzer, Kriston M. Strickler, and William B. Schill

Prepared in cooperation with the West Virginia Department of Agriculture

Scientific Investigations Report 2012-5087 


\title{
U.S. Department of the Interior \\ KEN SALAZAR, Secretary \\ U.S. Geological Survey \\ Marcia K. McNutt, Director
}

\author{
U.S. Geological Survey, Reston, Virginia: 2012
}

For more information on the USGS - the Federal source for science about the Earth, its natural and living resources, natural hazards, and the environment, visit http://www.usgs.gov or call 1-888-ASK-USGS.

For an overview of USGS information products, including maps, imagery, and publications, visit http://www.usgs.gov/pubprod

To order this and other USGS information products, visit http://store.usgs.gov

Any use of trade, product, or firm names is for descriptive purposes only and does not imply endorsement by the U.S. Government.

Although this report is in the public domain, permission must be secured from the individual copyright owners to reproduce any copyrighted materials contained within this report.

Suggested citation:

Stelzer, E.A., Strickler, K.M., and Schill, W.B., 2012, Interlaboratory comparison of three microbial source tracking quantitative polymerase chain reaction (qPCR) assays from fecal-source and environmental samples: U.S. Geological Survey Scientific Investigations Report 2012-5087, 10 p. 


\section{Contents}

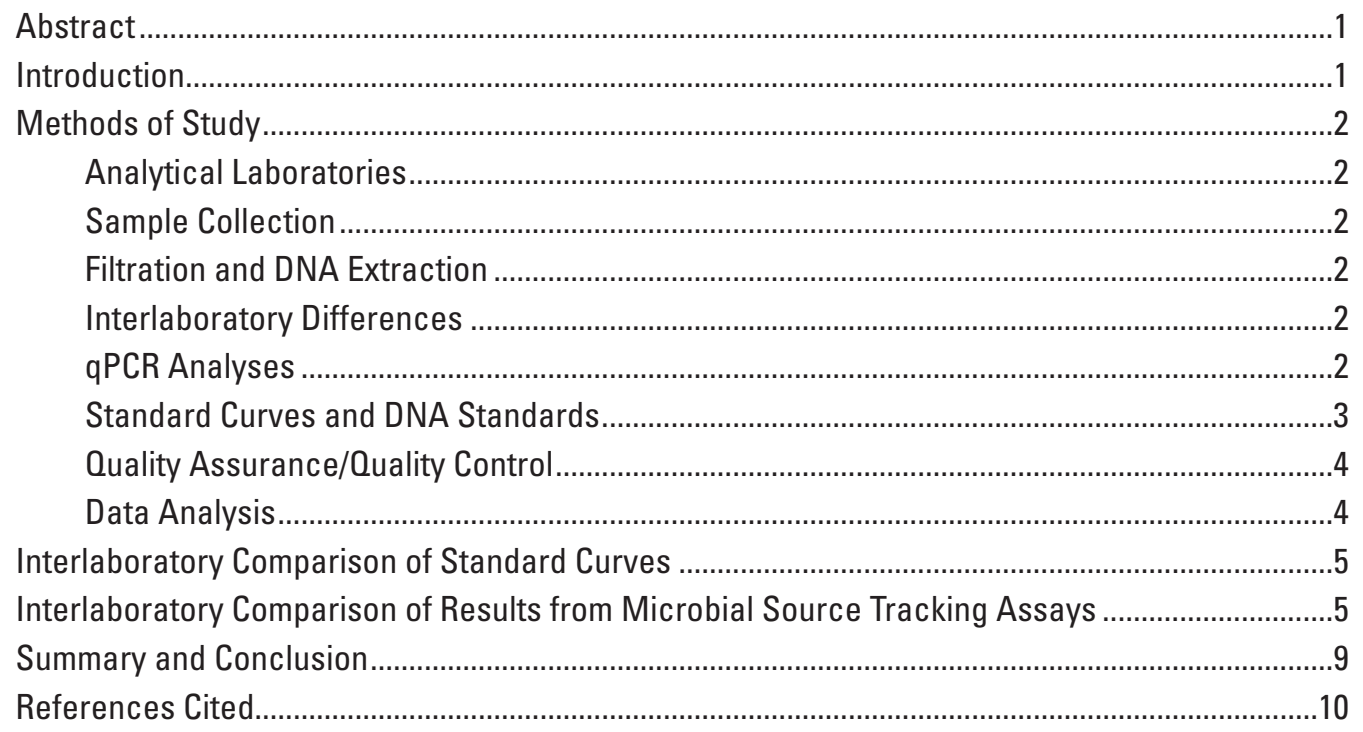

\section{Tables}

1. Equipment and analytical differences among laboratories ............................................3

2. Performance characteristics of quantitative polymerase chain reaction (qPCR) standard curves for each laboratory and microbial source tracking (MST) assay ..........5

3. Sample concentrations for all three microbial-source tracking (MST) assays from each laboratory....................................................................................................

4. Geometric means of absolute relative precent differences (ARPDs) for all samples and laboratories for each microbial source tracking (MST) assay before and after applying adjustment factors to sample concentrations for laboratory $3 . \ldots \ldots \ldots \ldots \ldots . . . . .8$

5. Friedman's and Tukey's studentized range multiple comparison statistical results for each microbial source tracking (MST) assay before and after applying adjustment factors to sample concentrations for laboratory 3 .

6. Geometric means of absolute relative percent differences (ARPDs) for all samples for individual laboratories for each microbial source tracking (MST) assay before and after applying adjustment factors to sample concentrations for laboratory 3 


\section{Conversion Factors and Abbreviations}

Inch/Pound to SI

\begin{tabular}{|c|c|c|}
\hline Multiply & By & To obtain \\
\hline \multicolumn{3}{|c|}{ Length } \\
\hline meter $(\mathrm{m})$ & 3.281 & foot $(\mathrm{ft})$ \\
\hline millimeter $(\mathrm{mm})$ & 0.03937008 & inch (in) \\
\hline micrometer $(\mu \mathrm{m})$ & 0.00003937 & foot $(\mathrm{ft})$ \\
\hline \multicolumn{3}{|c|}{ Volume } \\
\hline liter (L) & 33.8140227 & ounce, fluid (fl. oz) \\
\hline milliliter (mL) & 0.03381 & ounce, fluid (fl. oz) \\
\hline microliter $(\mu \mathrm{L})$ & 0.00003381 & ounce, fluid (fl. oz) \\
\hline \multicolumn{3}{|c|}{ Mass } \\
\hline $\operatorname{gram}(\mathrm{g})$ & 0.03527 & ounce, avoirdupois (oz) \\
\hline
\end{tabular}

Temperature in degrees Celsius $\left({ }^{\circ} \mathrm{C}\right)$ may be converted to degrees Fahrenheit ( $\left.{ }^{\circ} \mathrm{F}\right)$ as follows:

${ }^{\circ} \mathrm{F}=\left(1.8 x^{\circ} \mathrm{C}\right)+32$

\section{Abbreviations}

$\begin{array}{ll}\text { ANOVA } & \text { analysis of variance } \\ \text { ARPD } & \text { absolute relative percent difference } \\ \text { BSA } & \text { Bovine serum albumen } \\ \text { Ct } & \text { cycle threshold } \\ \text { CTAB } & \text { hexadecyltrimethylammonium bromide } \\ \text { DNA } & \text { deoxyribonucleic acid } \\ \text { E. coli } & \text { Escherichia coli } \\ \text { MST } & \text { microbial source tracking } \\ \text { NTC } & \text { sno-template controls } \\ \text { qPCR } & \text { quantitative polymerase chain reaction } \\ \text { USGS } & \text { U.S. Geological Survey } \\ \text { WVDA } & \text { West Virginia Department of Agriculture }\end{array}$




\title{
Interlaboratory Comparison of Results for Three Microbial Source Tracking Quantitative Polymerase Chain Reaction (qPCR) Assays from Fecal-Source and Environmental Samples
}

\author{
By Erin A. Stelzer1', Kriston M. Strickler², and William B. Schill ${ }^{3}$
}

\section{Abstract}

During summer and early fall 2010, 15 river samples and 6 fecal-source samples were collected in West Virginia. These samples were analyzed by three laboratories for three microbial source tracking (MST) markers: AllBac, a general fecal indicator; BacHum, a human-associated fecal indicator; and BoBac, a ruminant-associated fecal indicator. MST markers were analyzed by means of the quantitative polymerase chain reaction (qPCR) method. The aim was to assess interlaboratory precision when the three laboratories used the same MST marker and shared deoxyribonucleic acid (DNA) extracts of the samples, but different equipment, reagents, and analyst experience levels. The term assay refers to both the markers and the procedure differences listed above. Interlaboratory precision was best for all three MST assays when using the geometric mean absolute relative percent difference (ARPD) and Friedman's statistical test as a measure of interlaboratory precision. Adjustment factors (one for each MST assay) were calculated using results from fecal-source samples analyzed by all three laboratories and applied retrospectively to sample concentrations to account for differences in qPCR results among labs using different standards and procedures. Following the application of adjustment factors to qPCR results, ARPDs were lower; however, statistically significant differences between labs were still observed for the BacHum and BoBac assays. This was a small study and two of the MST assays had 52 percent of samples with concentrations at or below the limit of accurate quantification; hence, more testing could be done to determine if the adjustment factors would work better if the majority of sample concentrations were above the quantification limit.

${ }^{1}$ U.S. Geological Survey, Ohio Water Science Center, Columbus, Ohio.

${ }^{2}$ West Virginia Department of Agriculture, Regulatory and Environmental Affairs, Moorefield, West Virginia.

${ }^{3}$ U.S. Geological Survey, Leetown Science Center, Leetown, West Virginia.

\section{Introduction}

Microbial source tracking (MST) tools are currently (2012) being used as a means to differentiate fecal contamination sources (U.S. Environmental Protection Agency, 2005). MST tools are divided according to two basic approaches: library-dependent methods, which rely upon large collections of known-source fecal-indicator bacteria; and library-independent methods, which utilize host-associated genetic markers. The library-dependent methods are applicable to an unlimited range of hosts, but are prone to false-positive results (Griffith and others, 2003; Stoeckel and others, 2004). Library-independent methods are limited in the range of hosts, but are less prone to false-positive results than library-dependent methods (Griffith and others, 2003).

A commonly used group of library-independent MST markers relies on the detection of 16S rRNA-based genetic markers from the fecal anaerobes of the order Bacteroidales. These obligate anaerobes make up about one-third of the human fecal flora, far outnumbering coliforms (Holdeman and others, 1976; Salyers, 1984). Bacteroidales' host-associated markers have been used in several studies to detect human and ruminant fecal contamination (Boehm and others, 2003; Bower and others, 2005; Shanks and others, 2006; Seurinck and others, 2005; Kildare and others, 2007).

An emerging library-independent MST method is quantitative polymerase chain reaction (qPCR). This technique cannot only be used to detect, but also to estimate the amount of MST marker present in samples. Many systems capable of running qPCR are now commercially available, and there is concern about assuming comparability of results generated by different laboratories using protocols without common equipment, reagents, and standards.

The U.S. Geological Survey (USGS), in cooperation with West Virginia Department of Agriculture (WVDA), assessed interlaboratory precision in MST assay concentrations when the same MST markers were applied to shared samples; however, there were differences in the equipment, reagents, 
and standards between the analytical laboratories. Due to the lack of standardized protocols and quality control, results from different laboratories may vary and at this time there is little guidance on how to determine the true MST marker concentration by qPCR. Twenty-one samples were analyzed by three laboratories using three MST assays. All analyses by the different laboratories were performed on deoxyribonucleic acid (DNA) extracts from the same set of samples to eliminate variability associated with samples, sample handling, and DNA extraction. Each laboratory/analyst had a different level of qPCR experience: one was a novice, another had approximately 5 years of experience, and another had more than 10 years of experience. Understanding the interlaboratory precision when using different equipment, reagents, and experience levels would help MST researchers to compare data from multiple laboratories within one study or even compare similar MST data among multiple studies, which can be rather complicated.

\section{Methods of Study}

\section{Analytical Laboratories}

Three laboratories participated in this study: a West Virginia state laboratory and two Federal laboratories. A single analyst at each of the laboratories handled all of their laboratories' analytical work for this study.

\section{Sample Collection}

During September 2010, personnel from WVDA and the USGS in Charleston, West Virginia, collected seven river samples and six fecal-source samples in south-eastern West Virginia. All river samples were collected approximately $0.3 \mathrm{~m}$ below the water surface into sterile bottles using a grab-sampling technique (Myers and others, 2007). Fecal-source samples from chickens, cows, influent, and two effluent samples from a wastewater-treatment plant and a discharge pipe into a river were collected using sterile bottles or bags. Fecal-source samples were taken from farms or wastewater-treatment plants in the area, and chicken and cow feces were composited by species. Influent was collected by grab-sampling from the settling pond, and effluent was collected by grab-sampling from the wastewater-treatment plant.

The USGS in Leetown, West Virginia, provided eight additional river samples that were collected as part of another study during summer 2010. These samples were from sites in the Shenandoah Valley and were selected to be representative of surface-water samples that were thought to contain fecal contaminants from cattle, chicken, and human sources. These samples were collected in sterile bottles (as previously mentioned) and kept frozen until they were filtered and extracted.

\section{Filtration and DNA Extraction}

River and fecal-source samples collected in September 2010 were filtered and extracted by WVDA within 48 hours of collection. The chicken and cow source samples were made into slurries by adding $1 \mathrm{~g}$ of feces to $99 \mathrm{~mL}$ of sterile-phosphate buffer. All samples were concentrated by use of $47-\mathrm{mm}$ diameter, $0.4-\mu \mathrm{m}$ pore size polycarbonate filters (Whatman, Florham Park, New Jersey). After filtration, each filter was aseptically folded and placed into a $2.0-\mathrm{mL}$ screw-cap tube containing $0.3 \mathrm{~g}$ of acid-washed glass beads (Sigma, St. Louis, Missouri). Samples were extracted using a DNA-EZ extraction kit (GeneRite, North Brunswick, N.J.) according to manufacturer's instructions. The final extract volume for each sample was $200 \mu \mathrm{L}$, which was split into three tubes. One tube was kept by the laboratory that filtered and extracted and the other two tubes were shipped on dry ice to the other laboratories. All DNA extracts were stored at -20 or $-70^{\circ} \mathrm{C}$ until qPCR analysis.

Samples of river water $(1 \mathrm{~L})$ provided by USGS in Leetown, were filtered and extracted using a hexadecyltrimethylammonium bromide (CTAB) method (Karl and Bailiff, 1989; Ishii and others, 1998). Crude DNA was further purified using a Clean and Concentrator ${ }^{\mathrm{TM}}-5$ Kit (Zymo Research, Irvine, California). Purified DNA was eluted in $500 \mu \mathrm{L}$ of IDTE, pH 8.0 (Integrated DNA Technologies, Inc., Coralville, Iowa) and stored frozen at $-70^{\circ} \mathrm{C}$ until distribution to the other laboratories.

\section{Interlaboratory Differences}

The aim of this study was to do an interlaboratory comparison of results from MST assays. Sample processing up to qPCR was constant since samples were filtered and extracted by one laboratory and then distributed to the other laboratories. All laboratories had different analysts and used different qPCR systems and reagents. One laboratory used different qPCR reaction volumes and different DNA standard material; however, with accurate quantification these differences should not affect precision. Table 1 contains the differences that could influence the interlaboratory precision in this study.

\section{qPCR Analyses}

In all three laboratories, DNA extracts were analyzed for the same three MST markers using primer and probe sets as well as run conditions from previously published protocols: in each sample the AllBac marker (Layton and others, 2006) was used to estimate total Bacteroidales, the BacHum marker (Kildare and others, 2007) was used to measure human-associated Bacteroidales, and the BoBac marker (Layton and others, 2006) was used to measure ruminant-associated Bacteroidales. The term MST assay, when used in this report, refers to both 
the standardized marker listed above and the differences in protocol from each laboratory (table 1). In laboratory 1, all qPCR analyses were done using $5 \mu \mathrm{L}$ of DNA extract and $20 \mu \mathrm{L}$ of master mix containing Quantitect Probe PCR kit (Qiagen, Valencia, Calif.) and Bovine serum albumen (BSA) (Invitrogen, Carlsbad, Calif.) in Smartcycler or Smartcycler II (Cepheid, Sunnyvale, Calif.) thermocyclers. In laboratory 2, all qPCR analyses were done using $5 \mu \mathrm{L}$ of DNA extract and $20 \mu \mathrm{L}$ of master mix containing $2 \mathrm{x}$ Universal TaqMan Master Mix (Applied Biosystems, Foster City, Calif.) and BSA (Invitrogen, Carlsbad, Calif.) in a 7500 Real-Time PCR System (Applied Biosystems, Foster City, Calif.) thermocycler. In laboratory 3 , all qPCR analyses were done using $2 \mu \mathrm{L}$ of DNA extract and $10 \mu \mathrm{L}$ of master mix containing QuantiFast Multiplex PCR + R kit (Qiagen, Valencia, Calif.) and BSA (Sigma, St. Louis, Mo.) in a Corbett Rotor-Gene 3000 (Qiagen, Valencia, Calif.) thermocycler. See table 1 for all the differences that could influence the interlaboratory precision in this study.

After completion of the qPCR analyses, some qPCR systems offer the ability for the researcher to manually designate a cycle threshold $(\mathrm{Ct})$ value to determine at what point in the exponential phase the samples will be measured and the start of the baseline (the initial cycles of PCR during which there is little change in fluorescence signal) (Kephart and Bushon, 2009). All three laboratories used an automatic baseline determined by the individual system and, if allowed, manually set the threshold at a value they determined to be the best fit in the exponential phase, which then was used for all qPCR runs of the same assay in that laboratory. Sample concentrations were calculated as assay copy number per $100 \mathrm{~mL}$ using the standard curves from each laboratory:

Conc $=($ sample $C t-y$-intercept $) /$ slope $x$ (extraction elution volume/volume added to qPCR reaction) $x(100 \mathrm{~mL} /$ volume filtered $)$.

\section{Standard Curves and DNA Standards}

A standard curve is generated by plotting cycle threshold values against known quantities of DNA from serially-diluted standards. Results from this set of standard reactions then are used to determine a best-fit regression line. DNA concentrations of environmental and fecal-source samples are calculated using this standard curve regression line (Applied Biosystems, 2010).

Laboratories 1 and 2 used plasmid DNA standards created at laboratory 2 to develop their standard curves. A plasmid is a DNA molecule contained in some type of bacteria that is separate from, and can replicate independently of, chromosomal DNA. Plasmids promote gene transfer, and therefore, easily incorporate and retain non-native genes. A positive control for each MST assay was amplified by PCR and cloned into a PCR-TOPO plasmid (Invitrogen, Carlsbad, Calif.). The plasmid was transformed into Escherichia coli (E. coli) TOP10 cells, and recombinant bacteria were selected on

Table 1. Equipment and analytical differences among laboratories.

[qPCR, quantitative polymerase chain reaction; DNA, deoxyribonucleic acid]

\begin{tabular}{|c|c|c|c|}
\hline \multirow[t]{2}{*}{ Category } & \multicolumn{3}{|c|}{ Differences by laboratory } \\
\hline & Laboratory 1 & Laboratory 2 & Laboratory 3 \\
\hline Thermocycler & $\begin{array}{l}\text { Cephied } \\
\text { Smartcycler and } \\
\text { Smartcycler II }\end{array}$ & $\begin{array}{l}\text { Applied Biosystems } \\
7500 \text { Real-Time } \\
\text { PCR System }\end{array}$ & $\begin{array}{l}\text { Corbett } \\
\text { Rotor-Gene } \\
3000\end{array}$ \\
\hline qPCR reagents & $\begin{array}{l}\text { Quantitect Probe } \\
\text { PCR kit }\end{array}$ & $\begin{array}{l}\text { 2x Universal } \\
\text { TaqMan Master } \\
\text { Mix }\end{array}$ & $\begin{array}{l}\text { QuantiFast } \\
\text { Multiplex PCR + R kit }\end{array}$ \\
\hline qPCR reaction volumes & 5 microliters & 5 microliters & 2 microliters \\
\hline DNA standards & $\begin{array}{l}\text { Plasmids created by } \\
\text { laboratory } 2\end{array}$ & $\begin{array}{l}\text { Plasmids created by } \\
\text { laboratory } 2\end{array}$ & $\begin{array}{l}\text { Commercially } \\
\text { synthesized } \\
\text { standards }\end{array}$ \\
\hline $\begin{array}{l}\text { Analyst experience } \\
\text { levels }\end{array}$ & Novice & 5 years & $10+$ years \\
\hline
\end{tabular}


ampicillin-containing LB agar. Real-time TaqMan PCR was used to screen colonies for presence of the target insert, and isolated colonies were selected for overnight liquid-culture propagation. Plasmids were extracted from the transformed $E$. coli using UltraClean 6 Minute Mini Plasmid Prep kit (MoBio, Carlsbad, Calif.), and inserts were sequenced to confirm identity. Plasmids were quantified using the PicoGreen ${ }^{\mathrm{TM}}$ assay (Molecular Probes, Inc., Eugene, Oregon) and were serially diluted (10-fold dilutions) to generate standard curves.

Laboratory 3 purchased synthesized standards for each MST assay from Integrated DNA Technologies (Coralville, Ia.). Synthesized standards are commercially produced by artificially adhering a prescribed sequence of bases together to produce the target gene sequence. After quantification by laboratory 3 , these synthesized standards were serially diluted 100 -fold to generate standard curves. A single standard curve was analyzed with each batch of test samples in all three laboratories.

\section{Quality Assurance/Quality Control}

Quality-control samples for qPCR included no-template controls (NTCs) and qPCR positive controls. The NTCs were processed once per qPCR batch by using sterile moleculargrade water in place of DNA template. A standard curve was added to every qPCR batch as a qPCR positive control.

Matrix inhibition of the environmental and fecal-source samples was measured by use of the SPUD assay by laboratory 1 before laboratories 2 and 3 analyzed the samples (Nolan and others, 2006). Ct values for all samples were within two cycles of the expected value for the positive control, and thus, were not considered to be matrix inhibited.

\section{Data Analysis}

Precision refers to the ability of a measurement to be consistently reproduced. If a sample of water is analyzed two times, measurements that are close together in magnitude are said to have "good precision" (Kinzelman and others, 2011). The measurement of precision used in this report is the absolute relative percent difference (ARPD), determined as follows:

$$
A R P D=A B S(X 1-X 2) / \operatorname{Xavg} \times 100
$$

where

$X 1$ is concentration observed with the first replicate,

$X 2$ is concentration observed with the second replicate, and

$X_{\text {avg }}$ is average concentration $=((X 1+X 2) / 2)$.
When interpreting these results, the lower the relative percent difference, the greater the precision. The ARPD values were calculated using copy number per $100 \mathrm{~mL}$. Geometric means of ARPDs for a given assay were calculated to facilitate a qualitative comparison across laboratories.

Three different statistical tests were performed in order to have a more quantitative comparison of laboratories. Friedman's test (Friedman, 1940) was used to test the null hypothesis that the median concentrations from the laboratories for a given assay were equal, versus the alternative hypothesis that at least one of the medians is different. Concentrations from a given assay were ranked within blocks corresponding to the 21 unique samples, and each laboratory was considered a separate treatment within the block. An analysis of variance (ANOVA) test was run on the ranked laboratory data along with posthoc Tukey's Studentized Range multiple comparison tests (when ANOVA indicated significant differences) to facilitate pair wise comparisons of median concentrations among laboratories. All tests of significance were based on an alpha level of 0.05 .

It is common practice for researchers to use standardized controls that are analyzed by all laboratories participating in an interlaboratory comparison of methods (Vermeulen and others, 2009). Although not ideal, this practice may enable adjustment factors to be calculated and retrospectively applied to a laboratory's results if they significantly differ from the results of another laboratory. In this study, the fecal-source samples were used as standardized controls. Ratio adjustment factors were computed for laboratory 3 for each MST assay. The adjustment factors $(F)$ were computed (equation 3 ) and multiplied by the original results from laboratory 3 to account for its differences in method and controls.

where

$$
F=\frac{\sum_{n}^{i=1} \frac{X 1_{i}}{X 3_{i}}+\sum_{m}^{j=1} \frac{X 2_{j}}{X 3_{j}}}{m+n}
$$

$X 1_{i}$ is concentration for fecal source $i$ by laboratory 1 ,

$X 2_{i}$ is concentration for fecal source $i$ by laboratory 2,

$X 3_{i}$ is concentration for fecal source $i$ by laboratory 3 , and $n$ and $m$ are the numbers of fecal-source samples analyzed by laboratories 1 and 2, respectively. 


\section{Interlaboratory Comparison of Standard Curves}

Standard-curve performance characteristics data from all three laboratories are provided in table 2. Guidelines for interpreting standard-curve data are available in the Applied Biosystems StepOne and StepOnePlus Real-Time PCR Systems Reagent Guide (Applied Biosystems, 2010). The amplification efficiency of the qPCR should be 90-110 percent; an efficiency of 100 percent means an exact doubling of the target DNA sequence at each cycle. This corresponds to a slope of about -3.1 to -3.6 . In this study, the range of amplification efficiencies for all laboratories and all MST assays was 89 to 116 percent. Slopes ranged from -2.992 to -3.630 . The dynamic range describes the lowest and highest standards analyzed by each laboratory in copies per qPCR reaction. Laboratories 1 and 2 have similar dynamic ranges since they shared the same lot of plasmid standards. The y-intercept is the $\mathrm{Ct}$ value where the standard curve crosses the $\mathrm{y}$-axis at 1 copy of the target sequence DNA. The y-intercepts in this study ranged from 34.58 to 44.74 . The correlation coefficient $\left(\mathrm{R}^{2}\right)$ is used to assess the fit of the standard curve to the plotted data points. The closer the $\mathrm{R}^{2}$ value is to 1 , the better the fit. In this study, the $\mathrm{R}^{2}$ values ranged from 0.976 to 1.000 .

\section{Interlaboratory Comparison of Results from Microbial Source Tracking Assays}

Replicates of the 21 DNA extracts for the same three MST qPCR targets were analyzed by three laboratories. DNA concentrations for each sample, by laboratory and assay, are provided in table 3 . One or more of the differences in protocol from the three laboratories likely caused laboratory 3 to report much higher sample concentrations than did laboratories 1 and 2. In order to bring sample concentrations for laboratory 3 more in line with sample concentrations of laboratories 1 and 2 , adjustment factors were calculated and applied as described in the Data Analysis section of this report. The mean adjustment factors for AllBac, BacHum and BoBac were determined to be $0.42,0.38$, and 0.54 , respectively. The adjustment factors and original and adjusted sample concentrations for laboratory 3 are provided in table 3 .

Table 2. Performance characteristics of quantitative polymerase chain reaction (qPCR) standard curves for each laboratory and microbial source tracking (MST) assay.

$\left[\mathrm{R}^{2}\right.$, correlation coefficient; AllBac, general fecal indicator; BacHum, human-associated fecal indicator; BoBac, ruminant-associated fecal indicator]

\begin{tabular}{|c|c|c|c|c|c|c|}
\hline Assay & Laboratory & Slope & $y$-intercept & $\mathbf{R}^{2}$ & $\begin{array}{c}\text { Dynamic range } \\
\text { (copies/qPCR reaction) }\end{array}$ & $\begin{array}{c}\text { Amplification } \\
\text { efficiency } \\
\text { (in percent) }\end{array}$ \\
\hline AllBac & 1 & -3.630 & 42.85 & 0.991 & $46.6-4.66 \mathrm{E}+07$ & 89 \\
\hline AllBac & 2 & -3.584 & 38.44 & 0.999 & $46.6-4.66 \mathrm{E}+07$ & 90 \\
\hline AllBac & 3 & -2.992 & 34.58 & 0.996 & $120-1.20 \mathrm{E}+10$ & 116 \\
\hline BacHum & 1 & -3.477 & 39.93 & 0.999 & $45.1-4.51 \mathrm{E}+07$ & 94 \\
\hline BacHum & 2 & -3.527 & 38.72 & 0.999 & $22.3-2.23 \mathrm{E}+06$ & 92 \\
\hline BacHum & 3 & -3.230 & 43.59 & 0.999 & $120-1.20 \mathrm{E}+10$ & 104 \\
\hline $\mathrm{BoBac}$ & 1 & -3.336 & 44.74 & 0.976 & $46.3-4.63 \mathrm{E}+07$ & 99 \\
\hline $\mathrm{BoBac}$ & 2 & -3.540 & 42.59 & 1.000 & $36.2-3.62 \mathrm{E}+06$ & 92 \\
\hline BoBac & 3 & -3.315 & 38.01 & 0.999 & $120-1.20 \mathrm{E}+10$ & 100 \\
\hline
\end{tabular}


Table 3. Sample concentrations for all three microbial-source tracking (MST) assays from each laboratory.

[mL, milliliter; AllBac, general fecal indicator; BacHum, human-associated fecal indicator; BoBac, ruminant-associated fecal indicator; <, less than; --, sample not analyzed; bold values indicate concentration is at or below the limit for acurate quantification]

\begin{tabular}{|c|c|c|c|c|c|c|c|}
\hline $\begin{array}{c}\text { Sample } \\
\text { name }\end{array}$ & $\begin{array}{c}\text { Volume } \\
\text { filtered } \\
(\mathrm{mL})\end{array}$ & $\begin{array}{l}\text { Extraction } \\
\text { elution } \\
\text { volume } \\
\text { (mL) }\end{array}$ & & & $\begin{array}{l}\text { AllBac } \\
\text { copies/ } \\
100 \mathrm{~mL}\end{array}$ & & \\
\hline & & & $\begin{array}{c}\text { Laboratory } \\
1\end{array}$ & $\begin{array}{c}\text { Laboratory } \\
2\end{array}$ & $\begin{array}{c}\text { Laboratory } \\
3\end{array}$ & $\begin{array}{c}\text { Laboratory } \\
3 \\
\text { adjusted }\end{array}$ & $\begin{array}{l}\text { Computed } \\
\text { adjustment } \\
\text { factors }\end{array}$ \\
\hline River 2 & 500 & 0.2 & 42 & 40 & 99 & 41 & \\
\hline River 3 & 100 & 0.2 & 180 & 190 & 480 & 200 & \\
\hline River 4 & 100 & 0.2 & 200 & 210 & 480 & 200 & \\
\hline River 8 & 1,000 & 0.5 & 48 & 49 & 120 & 50 & \\
\hline River 9 & 1,000 & 0.5 & 54 & 54 & 130 & 54 & \\
\hline River 10 & 1,000 & 0.5 & 33 & 32 & 70 & 29 & \\
\hline River 11 & 1,000 & 0.5 & 57 & 56 & 140 & 58 & \\
\hline River 12 & 1,000 & 0.5 & 55 & 53 & 130 & 54 & \\
\hline River 13 & 1,000 & 0.5 & 44 & 43 & 98 & 41 & \\
\hline Source 4 & 20 & 0.2 & 1,300 & 1,200 & 2,900 & 1,207 & 0.43 \\
\hline Source 5 & 100 & 0.2 & 170 & 170 & 450 & 187 & 0.38 \\
\hline Source 6 & 100 & 0.2 & 170 & 170 & 360 & 150 & 0.47 \\
\hline
\end{tabular}


Table 3. Sample concentrations for all three microbial-source tracking (MST) assays from each laboratory.-Continued [mL, milliliter; AllBac, general fecal indicator; BacHum, human-associated fecal indicator; BoBac, ruminant-associated fecal indicator; <, less than; --, sample not analyzed; bold values indicate concentration is at or below the limit for acurate quantification]

\begin{tabular}{|c|c|c|c|c|c|c|c|c|c|}
\hline \multicolumn{5}{|c|}{$\begin{array}{l}\text { BacHum } \\
\text { copies } / 100 \mathrm{~mL}\end{array}$} & \multicolumn{5}{|c|}{$\begin{array}{c}\text { BoBac } \\
\text { copies } / 100 \mathrm{~mL}\end{array}$} \\
\hline $\begin{array}{c}\text { Laboratory } \\
1\end{array}$ & $\begin{array}{c}\text { Laboratory } \\
2\end{array}$ & $\begin{array}{c}\text { Laboratory } \\
3\end{array}$ & $\begin{array}{c}\text { Laboratory } \\
\mathbf{3} \\
\text { adjusted }\end{array}$ & $\begin{array}{l}\text { Computed } \\
\text { adjustment } \\
\text { factors }\end{array}$ & $\begin{array}{c}\text { Laboratory } \\
1\end{array}$ & $\begin{array}{c}\text { Laboratory } \\
2\end{array}$ & $\begin{array}{c}\text { Laboratory } \\
3\end{array}$ & $\begin{array}{c}\text { Laboratory } \\
\mathbf{3} \\
\text { adjusted }\end{array}$ & $\begin{array}{l}\text { Computed } \\
\text { adjustment } \\
\text { factors }\end{array}$ \\
\hline 9 & 10 & 25 & 10 & & 17 & 21 & 43 & 23 & \\
\hline 22 & 24 & 52 & 20 & & 20 & 22 & 36 & 19 & \\
\hline 34 & 14 & 110 & 42 & & 120 & 140 & 270 & 146 & \\
\hline 79 & 68 & 150 & 58 & & 110 & 110 & 220 & 119 & \\
\hline 78 & 14 & 110 & 42 & & 93 & 120 & 230 & 124 & \\
\hline 100 & 120 & 250 & 96 & & 74 & 87 & 110 & 59 & \\
\hline 110 & 120 & 240 & 92 & & 67 & 93 & 140 & 76 & \\
\hline 10 & 9 & 15 & 6 & & 27 & 33 & 57 & 31 & \\
\hline 36 & 39 & 88 & 34 & & 35 & 38 & 69 & 37 & \\
\hline 10 & 4 & 18 & 7 & & 16 & 26 & 43 & 23 & \\
\hline 25 & 28 & 59 & 23 & & 45 & 50 & 110 & 59 & \\
\hline$<1$ & 12 & 13 & 5 & & 44 & 47 & 100 & 54 & \\
\hline 12 & 17 & 41 & 16 & & 31 & 36 & 68 & 37 & \\
\hline 10 & 6 & 16 & 6 & & 43 & 46 & 96 & 52 & \\
\hline 24 & 27 & 61 & 23 & & 51 & 56 & 120 & 65 & \\
\hline 44 & 35 & 74 & 29 & 0.53 & 39 & 45 & 78 & 42 & 0.54 \\
\hline 8 & 140 & 480 & 185 & 0.15 & 2,700 & -- & 6,400 & 3,454 & 0.42 \\
\hline 490 & 530 & 1,200 & 462 & 0.43 & 480 & 490 & 930 & 502 & 0.52 \\
\hline 1,000 & 1,000 & 2,400 & 925 & 0.42 & 810 & 780 & 1,100 & 594 & 0.72 \\
\hline 33 & 39 & 110 & 42 & 0.33 & 57 & 39 & 64 & 35 & 0.75 \\
\hline 100 & 100 & 220 & 85 & 0.45 & 70 & 74 & 320 & 173 & 0.23 \\
\hline
\end{tabular}


Prior to adjustments, the geometric means of ARPDs for all three laboratories, by MST assay, were 23.1, 48.9, and 35.2 for AllBac, BacHum, and BoBac, respectively (table 4). Friedman's test indicated that at least one of the unadjusted laboratory concentrations was statistically different from the others for all three assays (table 5). The geometric means of ARPDs were substantially lower at 2.9, 19.4, and 11.2 for AllBac, BacHum, and BoBac, respectively (table 4), after adjustment of results for laboratory 3. Friedman's test on the adjusted concentrations did not indicate statistically significant differences among laboratories for the AllBac assay results; however, statistically significant differences still were indicated for both the BacHum and BoBac assays (table 5).

The differences in protocol used in laboratory 3 may have resulted in low precision of sample concentrations compared to laboratories 1 and 2. Adjustment factors applied to sample concentrations for laboratory 3 helped to heighten the precision across all three MST assays; however, BacHum and BoBac still showed statistically significant differences among the three laboratories. One possible reason why BacHum and BoBac still showed statistically significant differences
Table 4. Geometric means of absolute relative precent differences (ARPDs) for all samples and laboratories for each microbial source tracking (MST) assay before and after applying adjustment factors to sample concentrations for laboratory 3 .

$[n$, number of values included in the ARPD calculation; AllBac, general fecal indicator; BacHum, human-associated fecal indicator; BoBac, ruminantassociated fecal indicator]

\begin{tabular}{lccc}
\hline \multicolumn{1}{c}{ Assay } & n & \multicolumn{2}{c}{$\begin{array}{c}\text { Geometric mean } \\
\text { ARPD }\end{array}$} \\
\hline & & Unadjusted & Adjusted \\
AllBac & 21 & 23.1 & 2.9 \\
BacHum & 21 & 48.9 & 19.4 \\
BoBac & 20 & 35.2 & 11.2 \\
\hline
\end{tabular}

Table 5. Friedman's and Tukey's studentized range multiple comparison statistical results for each microbial source tracking (MST) assay before and after applying adjustment factors to sample concentrations for laboratory 3.

[AllBac, general fecal indicator; <, less than; ND, not done; BacHum, human-associated fecal indicator; BoBac, ruminant-associated fecal indicator; a $\mathrm{p}$ value $\leq 0.05$ is considered statistically significantly different; Tukey studentized range grouping are presented as letters, and laboratories with at least one letter in common do not differ significantly]

\begin{tabular}{|c|c|c|c|}
\hline Assay & Laboratory & $\begin{array}{l}\text { Friedman test } \\
\text { p value }\end{array}$ & $\begin{array}{l}\text { Tukey studentized } \\
\text { range grouping }\end{array}$ \\
\hline \multicolumn{4}{|c|}{ Unadjusted } \\
\hline \multirow[t]{3}{*}{ AllBac } & 1 & & \\
\hline & 2 & $<0.0001$ & \\
\hline & 3 & & \\
\hline \multirow[t]{3}{*}{ BacHum } & 1 & & \\
\hline & 2 & $<0.0001$ & ND \\
\hline & 3 & & \\
\hline \multirow[t]{3}{*}{ BoBac } & 1 & & \\
\hline & 2 & $<0.0001$ & \\
\hline & 3 & & \\
\hline \multicolumn{4}{|c|}{ Adjusted } \\
\hline \multirow[t]{3}{*}{ AllBac } & 1 & & \\
\hline & 2 & 0.3041 & ND \\
\hline & 3 & & \\
\hline \multirow[t]{3}{*}{ BacHum } & 1 & & A B \\
\hline & 2 & 0.0309 & A \\
\hline & 3 & & B \\
\hline \multirow[t]{3}{*}{ BoBac } & 1 & & A \\
\hline & 2 & 0.0012 & A B \\
\hline & 3 & & B \\
\hline
\end{tabular}


could be that 52 percent of the concentrations for these two assays were at or below the limit of accurate quantification and very near or at the detection limit of the assays, making them slightly more uncertain than concentrations for AllBac, which were almost all above the limit of quantification and well above the detection limit. All concentrations at or below the limit of accurate quantification are indicated in bold type in table 3.

In the interlaboratory comparison, laboratories 1 and 2 had the lowest geometric means of ARPDs for all three MST assays when using the unadjusted concentrations (table 6). After adjustments, the geometric means of ARPDs were lowest for laboratories 1 and 2 for AllBac (1.9), for laboratories 1 and 3 for BacHum (19.0), and for laboratories 2 and 3 for BoBac (8.0) (table 6). These results could be an artifact of how the adjustment factors were computed; therefore, more statistical tests were run. Tukey's Studentized Range test was run as a posthoc test if the ANOVA test indicated a significant difference. Tukey's Studentized Range test ranked laboratories against each other in terms of statistical similarities based on their sample concentrations. These tests were run only on adjusted concentrations from laboratory 3 to further explore the nature of the differences indicated in Friedman's tests using the adjusted concentrations for laboratory 3. Differences among laboratory results for AllBac were not statistically significant. Results for BacHum indicated that laboratories 2 and 3 had statistically significant differences, whereas results for BoBac indicated that laboratories 1 and 3 had statistically significant differences (table 5).

In both cases of statistically significant differences after adjustment (BoBac and BacHum assays), laboratory 3 was one of the laboratories singled out. This may be because many of the sample concentrations for these two assays were below the lowest point on the standard curve, and therefore, not as accurately calculated.

\section{Summary and Conclusion}

Microbial source tracking (MST) tools are commonly being used to help differentiate sources of fecal contamination in environmental waters. Currently (2012), there is a wide array of commercially available quantitative polymerase chain reaction (qPCR) systems and reagents, which has led to a concern about comparability of data generated by different laboratories using these different equipment and reagents. The U.S. Geological Survey, in cooperation with the West Virginia Department of Agriculture, assessed interlaboratory variability in MST assay concentrations when using the same MST markers and shared samples. Three laboratories shared deoxyribonucleic acid (DNA) extracts from 15 river and 6 fecal-source samples and ran each sample with three MST assays to determine if qPCR concentrations are interchangeable among laboratories. Each laboratory used different qPCR systems and reagents and one laboratory used different standards and qPCR reaction volumes. Results indicated that geometric mean ARPDs showing qPCR precision for laboratory 3 were all at or above 58.3, whereas the geometric mean ARPDs for just laboratories 1 and 2 were all at or below 19.2. Although not ideal, through the use of control samples that were analyzed by all participating laboratories, adjustment factors were applied to sample results for laboratory 3 , which brought the geometric mean ARPDs down to at or below 20.1. Technically, the use of different standards (if accurately quantified) and different qPCR reaction volumes should not have caused the large precision issue that was discovered in this study. As previously stated in this report, the use of the adjustment factors was not ideal, but needed in order to compare data from all the laboratories for this report. Therefore, additional study is needed to test interlaboratory variability with only one variable changing at a time and with all samples above the assay limit of quantification.

Table 6. Geometric means of absolute relative percent differences (ARPDs) for all samples for individual laboratories for each microbial source tracking (MST) assay before and after applying adjustment factors to sample concentrations for laboratory 3.

[n, number of values included in the ARPD calculation; AllBac, general fecal indicator; BacHum, human-associated fecal indicator; BoBac, ruminant-associated fecal indicator]

\begin{tabular}{|c|c|c|c|c|c|c|}
\hline \multirow[t]{2}{*}{ Assay } & \multicolumn{2}{|c|}{ Laboratories 1 and 2} & \multicolumn{2}{|c|}{ Laboratories 1 and 3} & \multicolumn{2}{|c|}{ Laboratories 2 and 3} \\
\hline & $\mathbf{n}$ & $\begin{array}{c}\text { Geometric mean } \\
\text { ARPD }\end{array}$ & n & $\begin{array}{c}\text { Geometric mean } \\
\text { ARPD }\end{array}$ & $\mathbf{n}$ & $\begin{array}{c}\text { Geometric mean } \\
\text { ARPD }\end{array}$ \\
\hline \multicolumn{7}{|c|}{ Unadjusted } \\
\hline AllBac & 21 & 1.9 & 21 & 80.3 & 21 & 81.0 \\
\hline BacHum & 21 & 19.2 & 21 & 78.5 & 21 & 77.7 \\
\hline $\mathrm{BoBac}$ & 20 & 11.5 & 21 & 65.8 & 20 & 58.3 \\
\hline \multicolumn{7}{|c|}{ Adjusted } \\
\hline AllBac & 21 & 1.9 & 21 & 4.7 & 21 & 2.4 \\
\hline BacHum & 21 & 19.2 & 21 & 19.0 & 21 & 20.1 \\
\hline BoBac & 20 & 11.5 & 21 & 15.5 & 20 & 8.0 \\
\hline
\end{tabular}




\section{References Cited}

Applied Biosystems, 2010, Applied Biosystems StepOne and StepOnePlus real-time PCR systems reagent guide, accessed July 26, 2011, at www3.appliedbiosystems.com/ cms/groups/mcb_support/documents/generaldocuments/cms_046739.pdf.

Boehm, A.B., Fuhrman, J.A., Mrše, R.D., and Grant, S.B., 2003, Tiered approach for identification of a human fecal pollution source at a recreational beach-Case study at Avalon Beach, Catalina Island, California: Environmental Science \& Technology, v. 37, no. 4, p. 673-680.

Bower, P.A., Scopel, C.O., Jensen, E.T., Depas, M.M., and McLellan, S.L., 2005, Detection of genetic markers of fecal indicator bacteria in Lake Michigan and determination of their relationship to Escherichia coli densities using standard microbiological methods: Applied and Environmental Microbiology, v. 71, no. 12, p. 8305-8313.

Friedman, M., 1940, A comparison of alternative tests of significance for the problem of $m$ rankings: The Annals of Mathematical Statistics, v. 11, no. 1, p. 86-92.

Griffith, J.F., Weisberg, S.B., and McGee, C.D., 2003, Evaluation of microbial source tracking methods using mixed fecal sources in aqueous test samples: Journal of Water Health, v. 1, no. 4 , p. 141-151.

Holdeman, V., Cato, E.P., and Moore, W.E.C., 1976, Human fecal flora-Variation in bacterial composition within individuals and a possible effect of emotional stress: Applied and Environmental Microbiology, v. 31, no. 3, p. 359-375.

Ishii, Nobuyoshi; Kawabata, Zen'ichiro; Nakano, Shin-ichi; Min, Man-Gi; and Takata, Renkichi, 1998, Microbial interactions responsible for dissolved DNA production in a hypereutrophic pond: Hydrobiologia, v. 380, p. 67-76.

Karl, D.M., and Bailiff, M.D., 1989, The measurement and distribution of dissolved nucleic acids in aquatic environments: Limnology and Oceanography, v. 34, no. 3, p. 543-558.

Kephart, C.M., and Bushon, R.N., 2009, Evaluation of realtime quantitative polymerase chain reaction (qPCR) to determine Escherichia coli concentrations at two Lake Erie beaches: U.S. Geological Survey Scientific Investigations Report 2009-5052, 14 p.

Kildare, B.J., Leutenegger, C.M., McSwain, B.S., Bambic, D.G., Rajal, V.B., and Wuertz, Stefan, 2007, 16S rRNAbased assays for quantitative detection of universal, human-, cow-, and dog-specific fecal Bacteroidales-A Bayesian approach: Water Research, v. 41, no. 16, p. 3701-3715.
Kinzelman, J.L., Bushon, R.N., Dorevitch, Samuel, and Noble, R.T., 2011, Comparative evaluation of molecular and culture methods for fecal indicator bacteria for use in inland recreational waters: Water Environment Research Foundation Final Report PATH7R09, 160 p.

Layton, A., McKay, L., Williams, D., Garrett, V., Gentry, R., and Sayler, G., 2006, Development of Bacteroides 16S rRNA gene TaqMan-based real-time PCR assays for estimation of total, human, and bovine fecal pollution in water: Applied and Environmental Microbiology, v. 72, no. 6, p. 4214-4224.

Myers, D.N., Stoeckel, D.M., Bushon, R.N., Francy, D.S., and Brady, A.M.G., 2007, Fecal indicator bacteria: U.S. Geological Survey Techniques of Water-Resources Investigations, book 9, chap. A7, section 7.1 (version 2.0), accessed August 17, 2010, at http://pubs.water.usgs.gov/twri9A/.

Nolan, Tania, Hands, R.E., Ogunkolade, William, and Bustin, S.A., 2006, SPUD-A quantitative PCR assay for the detection of inhibitors in nucleic acid preparations: Analytical Biochemistry, v. 351, p. 308-310.

Salyers, A.A., 1984, Bacteroides of the human lower intestinal tract: Annual Review of Microbiology, v. 38, p. 293-313.

Seurinck, Sylvie, Defoirdt, Tom, Verstraete, Willy, and Siciliano, S.D., 2005, Detection and quantification of the human-specific HF183 Bacteroides 16S rRNA genetic marker with real-time PCR for assessment of human faecal pollution in freshwater: Environmental Microbiology, v. 7, no. 2, p. 249-259.

Shanks, O.C.; Nietch, Christopher; Simonich, Michael; Younger, Melissa; Reynolds, Don; and Field, K.G., 2006, Basin-wide analysis of the dynamics of fecal contamination and fecal source identification in Tillamook Bay, Oregon: Applied and Environmental Microbiology, v. 72, no. 8, p. 5537-5546.

Stoeckel, D.M.; Mathes, M.V.; Hyer, K.E.; Hagedorn, Charles; Kator, Howard; Lukasik, Jerzy; O’Brien, T.L.; Fenger, T.W.; Samadpour, Mansour; Strickler, K.M.; and Wiggins, B.A., 2004, Comparison of seven protocols to identify fecal contamination sources using Escherichia coli: Environmental Science \& Technology, v. 38, no. 22, p. 6109-6117.

U.S. Environmental Protection Agency, 2005, Microbial source tracking guide document: Cincinnati, Ohio, Office of Research and Development, National Risk Management Research Laboratory, EPA/600/R-05/064, 123 p.

Vermeulen, J., Pattyn, F., De Preter, K., Vercruysse, L., Derveaux, S., Mestdagh, P., Lefever, S., Hellemans, J., Speleman, F., and Vandesompele, J., 2009, External oglionucleotide standards enable cross laboratory comparison and exchange of real-time quantitative PCR data: Nucleic Acids Research, v. 37, no. 21, p. e138. 



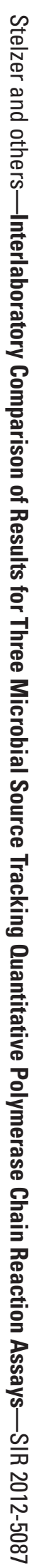

